development alternatives to official policies and, in other situations, in designing the official policies themselves. Some PRCs directly serve many business organizations. Many make a vital contribution in knowledge, training, information, and studies for booming nonprofit grassroots organizations, helping to build the Third Sector (nonprofit) and thereby provide development options not restricted to just the public and for-profit private sectors; in fact, many nonprofits are simultaneously PRCs and social action institutions. In their policy activities PRCs often function politically as think tanks. Furthermore, PRCs' net political impact is decidedly democratic, both in opposition to authoritarian regimes and in collaboration with their successors. Many PRCs assume a leadership role that intellectuals and university students have traditionally played in Latin America: a claim on national consciousness and identity.

The substantial success of PRCs contrasts with the emphasis on failure that characterizes much literature on comparative higher education, Third World research productivity, and philanthropy. The positive evaluation emerges as the analysis of PRCs ranges across issues of their definitional boundaries, the reasons for their growth and adaptability, the sources of finance and the control that may accompany that finance, the macropolitical questions related to PRCs under different regimes, and micropolitical questions related to intraorganizational governance. Success is qualified, however, by the fragility and dependence of most PRCs and by a series of academic weaknesses. PRCs are not adequate substitutes for good research universities; in some ways they even become obstacles to their development.

PRCs do not lead in every nation, much less in every aspect of social research, but a four-part categorization shows only two nations where PRCs clearly have less weight than universities in social research. The main categories are where the research is: (1) plentiful and mostly, or almost exclusively, packed into PRCs, (2) more limited yet impressively expanded and, again, packed mostly into PRCs, (3) developed in major part by both PRCs and universities. Attention to PRCs is attention to a vital part of higher education and provides new perspectives on the universities to which research centers have formed such attractive alternatives.

\section{The Emergence of Private Postsecondary Education in the Former Soviet Republic of Azerbaijan}

\section{James S. Catterall and Raymond McGhee, Jr}

James S. Catterall is professor and assistant dean, Graduate School of Education and Information Studies, University of California at Los Angeles. Raymond McGhee Jr. is an ESL teaching specialist with interests in the Middle East and an advanced doctoral student in comparative education and sociology of education at UCLA. This article is based on "The Emergence of Private Postsecondary Education in the Former Soviet Republics: A Case Study from the Caspian," a paper presented at the annual meeting of the American Educational Research Association, New York, April 1996. Available from Prof. James S. Catterall, Department of Education, University of California, Los Angeles, 405 Hilgard Ave. Los Angeles, CA 90095-1521.

7 he collapse of the former Soviet Union has propelled 1 its former republics along tortuous paths toward selfdetermination. Outside of Russia, less visible sagas are unfolding on the periphery in the Transcaucasian region and the Central Asian republics lying east of the Caspian Sea. These newborn national systems and their people face challenges that can only be called daunting. Their Soviet-developed institutions of higher learning presently lack support for basic operations and are literally crumbling apart. Moreover, the very values and orientations their citizens will need to succeed in a world free-market economy have been systematically denied and denounced over about four generations of Soviet control. So a change toward a Western and market orientation to the world, the sine qua non of economic advancement and even survival in the reasoning of most observers, represents a monumental undertaking-it calls for a reordering at the mindset level. This abstract, drawn from a longer work recently completed by the authors, presents a description of the conditions of change in the higher education system in the former Soviet republic of Azerbaijan, and the emergence of private postsecondary institutions in the present period of social transformation.

\section{Higher Education in Azerbaijan}

The system of higher education in Azerbaijan was a part of a massive system established by the former Soviet Union. The system was characterized by tremendous differentiation in types and missions of institutions. Higher education institutions were centrally financed and controlled 
through the education ministries. They existed to train citizens for all sorts of skilled roles in economic production, science, and culture. And the wide variety of higher education institutions that were established in the Soviet era continues to exist in present-day Azerbaijan: there are comprehensive universities in addition to smaller institutes focused on teacher training, foreign languages, technology (separate academies for engineering and petroleum sciences, for example), agriculture, law, economics, medicine, fine arts, and physical education.

\section{The collapse of the former Soviet Union has propelled its former republics along tortuous paths toward self-determina- tion.}

Although much of the structure and organization of higher education in Azerbaijan remains from the Soviet era, many of the specialized institutes and academies were reclassified as universities after the adoption of the Law of Education of the Azerbaijan Republic in October of 1992, promulgated by Azerbaijan's first post communist government.. This new law defined and legislated the general principles and structure of the entire education system in Azerbaijan and in addition permitted the establishment of private educational institutions.

\section{The Emergence of Private Higher Education}

No private institutions of higher learning existed within the Soviet system of higher education prior to perestroika in the latter 1980s. A small explosion of private institutions was touched off in 1991, and now more than 100 private postsecondary institutions have been established in Azerbaijan. Some key conditions collaborated to propel these institutions into existence. One factor was the general interest in privatization and the nascent experiments and trials with private enterprise pervading former Russian and Azeri society. Conditions in the public institutions of higher education produced extremely fertile circumstances for the emergence of private universities. Hard times and corrupt practices in the public higher education sector gave rise to many frustrations for young students and their families trying to make their ways in their newly independent world. If it was going to cost uncertain amounts of money to attend a state university, a private alternative might look more attractive.
Student life at the traditional institutions and work opportunities were also changing dramatically. Youth organizations that had played an important role in providing a variety of social and civic activities for students had decreased markedly. The disintegration of central control and financing left student life at traditional institutions in a state of flux and uncertainty. The increasing need for English-speaking graduates to work with the growing number of Western enterprises that had established themselves in Azerbaijan also created a new demand for trained graduates. Traditional institutions were failing and lacked direction; they are unable to pay their faculty regularly or adequately. The founders of the emerging private colleges and universities are among the few entrepreneurs who visualized this confluence of demand and supply and organized new institutions to effectively market and deliver a response.

Of the over 100 private postsecondary institutions in existence in Azerbaijan, 10 have acquired formal legal status after being evaluated by an expert commission appointed by the Ministry of Education and receiving approval from the government's Cabinet of Ministers. The proliferation of private educational institutions has raised some concerns over the quality of these institutions and their programs, thus prompting extensive government oversight in the areas of university certification, admissions, and financing. Many of these universities have carved out a niche offering a market-oriented curriculum, especially business management, economics, journalism, English translation, and law. Students and their families believe these new private universities offer their children Western contacts and valuable academic and language skills because their faculty have traveled to the West, and because they are promising Western-oriented curricula.

\section{The Future of Private Higher Education}

Private higher education in Azerbaijan faces many uncertainties in its environment-unstable monetary systems, changes in government policy, shifting terms of public charters, corruption, and influence peddling - not the best of conditions for doing business. Nevertheless, private institutions of higher education have positioned themselves to play a key role in the process of nation-building and global integration as well as meeting the increased demand for higher education related to production, trade, and human services. This trend of institutional diversification and pluralism represents a major shift from the uniform way of operating during the Soviet period. And buoyed by the 
prospect of future capital infusions into its faltering economy from future petroleum production and Western investment, Azerbaijan is hoping that its economy can become more productive with the help of trained graduates from the private sector. Only time will tell whether the private university sector will gain the kind of credibility and stability that will allow these institutions to play an important role in the advance of civil society in the former Soviet republics.

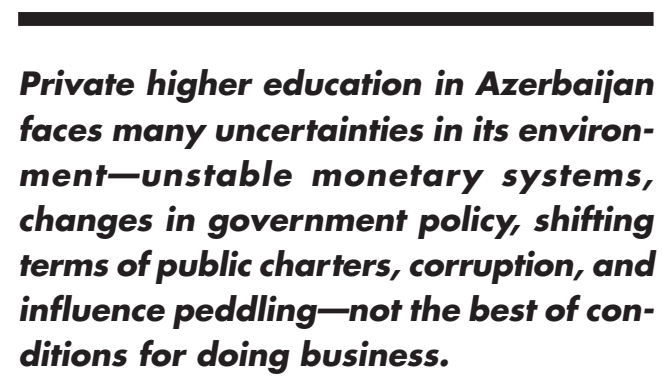

A longer version of this paper includes a case study of a leading private university in Baku, the capital city of Azerbaijan, and is available from the author. As of spring 1996 , this institution is completing its third year of operation and serves approximately 2,000 students who pay as much as $\$ 1,000$ per year in tuition. Most of its faculty formerly served in the state system of higher education and many earned their degrees in Moscow. Almost all instruction is conducted in English. The analysis focuses on the nature of English-language teaching at this university, the attempts of instructors to move away from traditions of direct, didactic teaching, and the overall strategic planning activities, and efforts to promote faculty governance in this institution.

\section{Renewing the Goals of Catholic Higher Education in Asia}

\section{Brother Andrew Gonzalez, FSC}

Brother Andrew Gonzalez, FSC, is president of De La Sale University, 2401 Taft Ave., Manila, Philippines. Fax: 632-526-1403

W hen the first institutions of higher learning were established in Asia, the oldest one being the University of Santo Tomas in the Philippines (1611), their goal was an evangelization-related one, in line with the reality that their founders were for the most part missionary religious workers. To put it as bluntly as possible, even at the risk of oversimplification, these institutions were not founded as centers of intellectual excellence where the propagation and production of knowledge for its own sake were the primary goals. These institutions were seen as a means of attracting the indigenous population toward the new knowledge of the colonial masters and its benefits and in the process maintaining the new links with the institutional Church, allowing a period of further internalization of the new religion in the locals' minds and in their emotions as well as attitudes. This primal motivation seems to be imprinted upon those involved in Catholic education even today for even now, administrators and faculty, especially religious personnel and concerned laymen and laywomen, worry about the faith and morals of their Catholic students in these universities.

Like the learning brought by De Nobili to India and by Ricci to China, higher education was a means of evangelization through attracting nonbelievers to what the Church had to offer in the field of Western knowledge and especially science, in the process keeping believers in a protected atmosphere where their faith could mature. As universities took on a more pragmatic purpose as institutions of training for the professions, Catholic institutions began to offer professional studies, again to attract converts and to keep believers in the faith.

One surmises that the same motivations undergirded Protestant universities in my part of the world, for evangelization was an all-consuming concern. However, because of many factors present in Protestantism but not in Catholicism, the move toward excellence in knowledge for its own sake and in research began much earlier among Protestant institutions. The traditionally intellectually oriented religious-such as the Dominicans and the Jesuits, espe- 